\title{
The Extent of Applying the Balanced Scorecard at the Jordanian Universities: Comparative study between the Government and Private Universities
}

\author{
Professor Walid Zakaria Siam \\ Professor of Accounting, The Hashemite University, Jordan \\ Rami Najeh Al-Masri \\ Master of Accounting and Finance \\ The Hashemite University, Jordan
}

\begin{abstract}
This study aims to identify the application extent of Balanced Scorecard (BSC) in Jordanian universities, and the variation extent in application between government and private Universities. It also aims to identify the obstacles (limitations) that limit the application of (BSC) in Jordanian Universities, and indicate whether these constraints (limitations) vary between government and private Universities. To achieve objectives of the study, the researchers prepared a questionnaire which was distributed in Jordanian government and private universities, total of (28) Universities (10 government universities and 18 private universities) (according to Jordanian Ministry of Higher Education and Scientific research Statistics of 2017). Questionnaires were distributed to financial managers, internal auditing managers, quality control and assurance managers, heads of accounting departments and employees working in finance departments of these universities. The study concluded many results. Important ones can be summarized as follows: The Jordanian universities apply the Balanced Scorecard (BSC) in a moderate degree. There is variation in the implementation degree of the Balanced Scorecard (BSC), in favor of the Jordanian private universities. There are constraints (limitations) limit the application of the Balanced Scorecard (BSC) in Jordanian universities (government and private) in a moderate degree. There is a slight variation in the existence degree of constraints (limitations) that limit the application of the Balanced Scorecard (BSC) between government and private universities in favor of the private universities. In the light of this study results, the researchers presented a set of recommendations including: importance of providing appropriate environment for application of the Balanced Scorecard (BSC) in the government Jordanian universities and more attention in applying to reach a high degree similar to the private Jordanian universities. Joint efforts must be combined between the Jordanian government and private universities to curb constraints (limitations) in the application of the Balanced Scorecard (BSC) efficiently.
\end{abstract}

Keywords: Balanced Scorecard, Jordanian government and Private Universities.

\section{INTRODUCTION}

The rapid changes and developments in modern business environment have affected the quality and quantity that the organizations need in order to measure and evaluate performance and in seek of achieving its strategic goals. And an urgent need to develop standards that goes along with standards of traditional financial performance has emerged, because standards of traditional financial performance have failed to keep pace with the rapid and successive changes in information and communication technology as well as the intensive competition between institutions. 
If the organizations are seeking to achieve a competitive advantage, that enables them to achieve operational and strategic objectives efficiently and effectively, and if their operators believe in the importance of the two factors performance measurement and evaluation, and that they are one of the main factors for the success of the organization in light of the rapid development in the working environment of these institutions of different types, as relying on traditional financial indicators is no longer enough.

Therefore, in light of the lack of traditional financial indicators in evaluating the performance of institutions, the researchers Kaplan Robert \& Norton David proposed the (Balanced Scorecard) (BSC) in 1992, to expand the framework of performance measurement to include, in addition to the financial aspects, other perspectives related to non-financial aspects. The balanced Scorecard contains the following four perspectives: financial perspective, customer perspective, internal process perspective, learning and growth perspective.

As the Jordanian universities are considered from the organizations that are highly concerned with the assessment of strategic performance, in order to achieve optimum use of resources, enabling it to achieve its strategic and operational objectives, it is important to apply the Balanced Scorecard (BSC) in a comprehensive and integrated manner, and working on reducing obstacles that minimizes the implementation of balanced scorecard effectively and efficiently.

\section{Importance and objectives of the study}

The study derives its importance from a set of points that can be summarized as follows:

- It studies the extent of applying the Balanced Scorecard with its four perspectives, which is considered an important managerial accounting method in the evaluation process, not to mention its developed style, which requires a lot of assessment tools, where financial and non-financial metrics contribute in measuring the extent of services development in a way that to optimize the cost of service in a fashion that leads to achieve the highest return.

- It studies the extent of the application of the Balanced Scorecard in an important sector, which is university education sector represented by public and private Jordanian universities, which play a significant role in the higher education sector, and these universities are dynamic organizations that employ the human, physical and dynamic energies and potentials, thus they need to adopt the best ways to promote the positive aspects of performance, which include the Balanced Scorecard.

- It identifies constraints (limitations) facing the application of this new method which is very important with its various perspectives in the evaluation of Jordanian universities' performance, consequently the results of this study will be useful for decision makers at Jordanian universities as it provides them with information about obstacles faced during the application of the Balanced Scorecard and the ways to overcome it.

- This study is considered one of the few studies (if not the first one) that researches (in a comparative approach between private and public universities) the extent of applying the Balanced Scorecard in light of competition in private university sector locally and regionally. Its operators must bear in mind that succeeding in competition must be based on providing distinguished educational services with high quality and ability to cope with developments and future aspirations. which requires a competent evaluation of its performance and ensuring cost rationing of the provided educational services in a manner that achieve the highest return and guarantees maintaining the quality of the educational process.

From this the study derives its importance. The researchers seek through this study to identify the extent of applying the Balanced Scorecard in Jordanian Universities by conducting a comparative study between public and private universities. 


\section{Sub-objectives of the study can be formulated as follows:}

1. Studying the extent of applying Balanced Scorecard in Jordanian Universities.

2. Identifying the extent of variation in applying Balanced Scorecard between public and private universities.

3. Identifying obstacles (limitations) that restrict applying the Balanced Scorecard in Jordanian Universities.

4. Highlighting the extent of variation in obstacles (limitations) that restricts applying Balances Scorecard between public and private Jordanian universities.

\section{Problem of the study}

The application of Balanced Scorecard in Jordanian universities requires researching wither the applied accounting system in these universities with its components and elements is able to operate with Balanced Scorecard as an approach of untraditional accounting approaches as well as to present it as desired. Or the elements of the accounting system in these universities require developing to become capable of operating with Balanced Scorecard as a mean to achieve balance in performance standards for it include financial or non-financial measurement indicators to meet the sustainable development purposes sought by all economic units.

The problem of the study can be formulated in the following questions:

- What is the extent of applying Balanced Scorecard in Jordanian universities?

- Is there a variation in applying Balanced Scorecard among public and private Jordanian universities?

- What are the obstacles (limitations) that restrict the application of Balanced Scorecard in Jordanian universities?

- Is there variation in obstacles (limitations) that restricts the application of Balanced Scorecard among public and private Jordanian universities?

\section{Theoretical Framework and Previous Studies}

Standards of financial performance was criticized a lot, some dating back to the lack of these standards to keep pace with changes and developments in the business environment. Traditional financial standards are seen as an unsuitable tool to determine the extent of safety performance, and ineffective to guide the attention of the administration to glitches and lack of efficiency, and inappropriate to direct the management and guide it towards how to improve the competitive position of the business to ensure its continuity and growth.

As a result of criticism of the conventional standards of financial performance and the evolution of the cognitive environment and increased competition between enterprises, most facilities have tended to look for a new performance appraisal system combines the use of nonfinancial standards as well as financial standards, until was reached to Balanced Scorecard.

Balanced Scorecard has formed what could be described as an intellectual revolution in the field of management accounting, specifically in the development of measurement techniques and performance evaluation. Hence, we should focus on that this revolution wasn't related only on using different measurements, whether financial or non-financial, but on building a participatory model coherent combining these measurements by creating overlapping or duplex flow between what these measurements represent of dimensions. This forms a state of interaction within the concept of action and reaction, or on the basis of cause and effect (AlKhatatneh \& Al-Sa`aydeh, 2009). 
Balanced Scorecard as seen by (Kaplan \& Norton, 1992) is a system that offers a coherent set of ideas and principles and a holistic path map for enterprises to track the translation of message in a coherent set of performance measures, these standards contribute in putting a business strategy and implementing it and assist in the coordination between the individual and organizational performance down to management objectives. They also defined it as: stereotyping and guide the company's activities and its business in four perspectives (financial perspective, customer perspective, internal processes perspective, and learning and growth perspective), each perspective contains a number of measures which are considered engines for the company's success and progress. These perspectives interact with each other through the relationship between performance engines for each perspective with performance engines of other perspectives, to translate company's strategies and plans into business and activities that are easy to manage and control.

(Kaplan et al., 2011) looks at the Balanced Scorecard as :A system for measuring performance in an orderly, thereby translate strategy into clear objectives, and a set of appropriate performance appraisal standards, while providing performance standards linked to a range of business programs that should be undertaken to achieve those goals.

(Bhimani et al., 2015) defines Balanced Scorecard as: a way to convert an enterprise's message and its strategies to performance measures, and that the structure of the Balanced Scorecard is based on putting measurements for each perspective of the perspectives, and make the process of measurements to compare the actual performance of the planned performance. Thus, the Balanced Scorecard translates mission and strategies of the company to a set of performance measures that represent a framework for the application of its strategies. This card is an assessment tool, as well as being a strategic tool that depends on four perspectives to evaluate the performance of the company rather than focusing on the financial perspective only, although its importance, but it is not enough to form a comprehensive picture about the company, as it became known that the conventional measures that focus on the financial dimension is not sufficient to the contemporary environment, and the interest in a wider range of measurements related to quality, market size, customer and staff satisfaction can lead to greater insight into the marketing of financial performance factors.

The Balanced Scorecard is essentially based on four perspectives to measure the overall performance of the organization, when (Kaplan \& Norton) in 1992 presented a Balanced Scorecard model, they formulated it in the form of a translation of the message and the vision of the organization to goals and performance measurements which are expressed through four main perspectives, as in the following figure (Figure (1)), namely:

1. Financial perspective: how the organization appears to owners?

2. Internal processes perspective: what are the processes that surpass the organization?

3. The customer perspective: How does the customer look at the organization?

4. Learning and growth perspective: How the organization will develop its economic potential? 


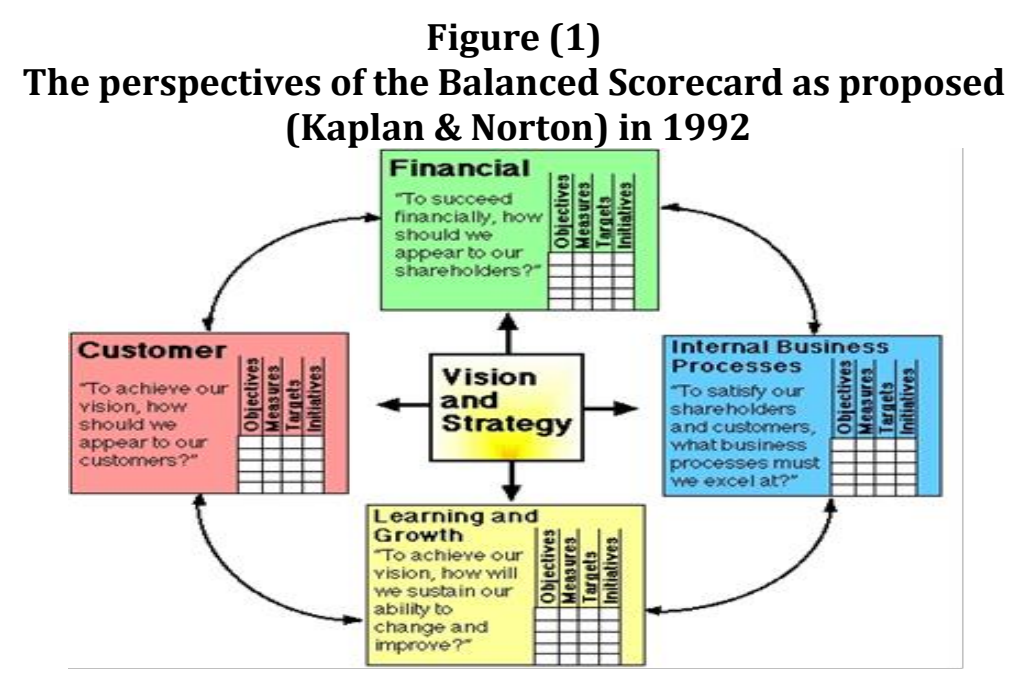

Source: Kaplan \& Norton, 1992, p. 74

And the four perspectives of the Balanced Scorecard in universities (like all organizations that apply Balanced Scorecard) are dependent as an array interconnected in the data collection and analysis, and allows measurement on various fields level, and these perspectives are:

\section{First, customer perspective (students):}

The attention of the university departments is directed to meet the students' needs and desires (without compromising the quality of the educational process), because these students are the ones who are paying for the university to cover their costs and make a profit.

The customer perspective (students) explains multiple performance measures of the output of the strategies formulated and implemented well by the university departments, these standards include in general, student satisfaction, retention methods, and the acquisition of new students; determine the profitability of the students and to identify the university's share in the market of the target segments.

This perspective revolves around the search for a definitive answer to the following questions:

1. How should the university appear to its current clients (students)?

2. How the university can achieve the greatest satisfaction of their needs and earn their loyalty?

3. How can the university attract new clients (students), after taking into account the profitability of each of them, as well as maintaining the quality of its output?

The customers (students) perspective is measured by:

- Student satisfaction: expresses the work results carried out by the university.

- Retention of students: to be made by observing the student to continue his studies at the same university for several stages of study.

- Students gain: measured by knowing the types and numbers of students who were acquired and entered the university.

- Student profit: is considered as a determinant to verify the extent of success in university's various strategies.

- Market share of university: we can obtain through this measure an appropriate assessment of the success of the university's strategy and activities that have been implemented to achieve this strategy. 


\section{Second, internal processes perspective}

In this perspective the effectiveness of the internal systems of the university is measured in order to ensure its competitiveness, the renewal system is one of the most important systems which include: Research, the number of patents, the number of products (specializations), in addition to the production system, including: product quality (learning outcomes), production deadlines (students graduation), and the system of after-sales service (after graduation) is also one of the important systems, including: Follow-up of graduates affairs, solve problems they may face at the beginning of their working lives.

This dimension focuses on internal processes that enhance both the axis of customers (students) enhancing customer value (students), and the financial axis to increase the wealth of shareholders (owners). Identify loops that will improve the goals and help address the distractions, and the development of performance and internal processes, in an effort to satisfy customers (students) as well as the shareholders (owners) (Kaplan \& Norton, 2004).

The executive departments of the universities determine internal processes that the university should overtake, where internal operations represent a group of activities that give the university a competitive advantage in the local and regional market.

The standards of internal processes identified by the university departments focus on processes that will add value, and have a positive impact in influencing customer satisfaction (the student), and thus achieve the financial objectives of the university.

And this perspective contains a group of different processes, which are:

1. Operational processes: operational processes enable the management of the university to find value, where the university provides available services for students.

2. Administrative processes: Administrative processes enable the management of the university to find value, where the university facilitates administrative procedures for students' transactions.

3. Regulatory and social processes: Enables the university administration to find value, where the university conducts the educational process and the provision of convenient social atmosphere for students.

4. Creative processes (innovation): where the university conducts research and studies to reveal the ongoing needs of the students, and then find the facilities and services that meet and satisfy these needs.

\section{Third, learning and growth perspective}

This perspective identifies the infrastructure that must be built by the university to achieve long-term growth and improvement, this interest in perspective of learning and growth comes through the discovery of large gaps between the capabilities and skills of workers, and the disparity in regulations and procedures accuracy, which requires the university administration to bridge these gaps by re-equipping its staff with the skills, and the promotion of information technology, systems and Consolidation of procedures and business.

It is worth mentioning that the interest dimension of learning and growth comes to strengthen other perspectives of the Balanced Scorecard, for example, the success of the customers (students) perspective depends on the efficiency and skill of workers, as the student satisfaction is achieved in the case of receiving a quality service, and this cannot be achieved without the presence of satisfaction and loyalty among workers toward their work, so it is sometimes seen that student satisfaction in one of its aspects is achieved as a continued impact for employee satisfaction, And employee satisfaction can be measured through the work of periodic surveys carried out by the university administration or a third party, and employee 
satisfaction surveys are based typically on a statement the evaluation and satisfaction of employee for a range of elements (Kaplan \& Atkinson, 1998, p. 368), which are:

1. Participation in decision-making.

2. Recognition of the employee when his work is done successfully.

3. Securing the employee with appropriate information needed for his work.

4. Receiving encouragement upon showing skills.

5. The continued support of all administrative centers.

6. Overall satisfaction of work site.

Managers must aims through their work strategy to keep the employee, because the expert employee represents the value of the university, which is part of the cultural and cognitive university's capital. The experience acquired by the employee through time factor is considered as success and progress of the university, and therefore the university must maintain these experiences.

\section{Fourth, financial perspective}

Financial results represent value for shareholders, because it sums up the economic measurable results of the procedures actually taken in the performance of work and activities of the university. The financial performance measures show to what extent the proposed strategy was viable or execution, and degree of success in its application or implementation and the extent of their contribution to the improvement of the main objectives of the university.

This perspective is the final outcome of the activities of the university, to achieve the satisfaction and expectations of shareholders and community by increasing the value of their investments and increase their profits. This perspective can be summarized by searching for an answer to the following question: How should the university appear to their shareholders and to society?

It is noted that the financial perspective in the Balanced Scorecard shows the success of the university in the implementation of various strategies, and reflects a comprehensive perspective of the performance of the university towards the parties that have to do with it.

In summary, the four-dimensional (customers (students) dimension, internal processes dimension, learning and growth dimension, and the financial dimension) that have been reviewed, are only the actual translation and detailed strategy for the university, where the university administration to convert this strategy into a viable and measurable objectives, depending on the university's ability to formulate strategy and put it clearly to all its sections, departments and faculties.

The basic features of the Balanced Scorecard can be assembled in the following key points (Zaghloul, 2010; Hussein, 2015; Bhimani et. al., 2015; Kaplan et. al., 2011):

1. The Balanced Scorecard is a four-dimensional model from four perspectives on which it's based on, a financial performance perspective, relations with customers' perspective, internal processes perspective and the perspective of learning and growth processes.

2. Balanced Scorecard divides each perspective to all basic components: subsidiary strategic goal, indicators, target values, procedural steps and initiatives.

3. The Balanced Scorecard is based on the blending of financial indicators and non-financial indicators in order to identify the extent of progress towards achieving the strategic objectives quantified and financially. 
4. The Balanced Scorecard connects key performance indicators of financial and nonfinancial for each perspective with their subsidiary strategic objectives derived mainly from organization business strategy.

5. Balanced Scorecard is characterized with a limited number of key performance indicators, based on the limited maturity property, property and lack of access to more than analytical energy information to the decision maker.

6. Balanced Scorecard requires the availability of refined information system and IT infrastructure, allows the use of the report software systems, to flow of information both horizontally and vertically on time.

7. Balanced Scorecard provides an orderly route linking the future vision of the establishment with its material and human resources to achieve the best investment of these resources.

Some researchers pointed (Al-Gharib 2012; Ahmed 2014, Al-Azab 2015; Hussein, 2015; Mubaideen 2015) that there are many obstacles (determinants), which could face the application of the Balanced Scorecard, and limit the effectiveness of the application, and from those obstacles (determinants) the following:

1. Lack of knowledge about the Balanced Scorecard as a tool used to measure the performance, or lack of knowledge of the benefits derived from its use.

2. Shareholders and some departments believe that the application of non-financial dimensions of the Balanced Scorecard carries additional costs for the facility that are indispensable.

3. Translation of the vision and mission of some facilities (such as hospitals and universities) to multiple strategic dimensions may not be appropriate to the nature of the work of those facilities.

4. Lack of qualified staff who are able to deal with the Balanced Scorecard, which leads eventually to resist the application of its dimensions, this generates negative attitudes in the staff towards the usage of Balanced Scorecard especially that they don't realize clear goals for it.

5. The inability of the strategic decisions of some facilities (such as hospitals and universities) to the requirements of customers (patients and students) and their needs, as they might be at the expense of the quality of services provided and its suitability.

6. Lack of appropriate measurements for some performance variables, since the existence of these measurements is important to put strategies under execution, so the lack of measurements to measure a variable leads to a lack of management capacity to direct their performance towards that variable.

As a brief overview of higher education and official and private universities sector, the higher education sector in Jordan leads a major and significant role in bringing about overall development of the various fields, the Higher Education in Jordan has achieved over the past decade significant progress in terms of the diversity of courses and learning styles and education that controls the quality and quantity, expansion of higher education institutions, and in spite of the limited human and material resources in Jordan, but that higher education is among the priorities of the state because of its active role in upgrading the economic, social and cognitive lives of citizen (www.mohe.gov.jo).

The higher education sector in Jordan witnessed over the past two decades, sophisticated and remarkable growth, confirmed by the increase in the number of higher education institutions and the number of enrolled students, faculty and members of the administrative board, and the increase in the volume of spending and government support for this important educational sector. 
This increase in the number of universities was accompanied with increase in numbers of students in them. The number of students (female and male) in public and private Jordanian Universities are estimated to be approximately (236) thousands, (28) Thousands of them are from Arab and foreign countries.

The educational role of Jordan became an active role in the region. It became the focus of attention and admiration for it was known with its high quality. This is reflected by the number of foreign students who study in Jordanian Universities which is approximately (28) thousands, females and males, from around the world. In addition to the increased polarization of graduates of Jordanian Universities to work in Arabic and regional organizations and general and private sectors.

The vision, mission and values of The Ministry of Higher Education's activities and objectives reflect on Jordanian Universities and their performance. The vision of Ministry of Higher Education and Scientific Research can be summarized in (A distinguished international Higher Education) while its message is ( Enabling Higher Education Institution to focus on its tasks and responsibilities through supporting it and following up the implementation of the strategies and politics of higher education that is based on directing towards competitiveness in establishing integrity standards and techniques of reinforcing principles of accountability, justice and transparency in providing support and special services for Higher Education students as well as in embracing leadership, excellence and creativity within the concept of participatory with the private sector).

The following table (Table 1) shows the names of Jordanian Universities (Public and Private):

Table No. (1)

Jordanian Universities (Public and Private) at the beginning of 2016

\begin{tabular}{|c|c|}
\hline $\begin{array}{l}\text { University } \\
\text { Sector }\end{array}$ & University \\
\hline $\begin{array}{l}\text { Public } \\
\text { Universities } \\
\quad(10 \\
\text { Universities })\end{array}$ & $\begin{array}{l}\text { The University of Jordan, Yarmouk University, Mutah University, Jordan } \\
\text { University of Science and Technology, Hashemite University, Al al-Bayt } \\
\text { University, Balqa Applied University, Al-Hussein Bin Talal University, Tafila } \\
\text { Technical University, the German Jordanian University. }\end{array}$ \\
\hline $\begin{array}{c}\text { Private } \\
\text { Universities } \\
\text { (18 } \\
\text { Universities) }\end{array}$ & $\begin{array}{l}\text { Amman Private University, Amman Arab University, Middle East University, } \\
\text { Jadara University, Al-Isra University, Petra University, Philadelphia University, } \\
\text { Irbid National University, University of Applied Sciences, Al-Zaytoonah } \\
\text { University of Jordan, Zarqa University, Princess Sumaya University of } \\
\text { Technology, University of Jerash, Jordan Academy of Music, Jordan Applied } \\
\text { University College of Hospitality and tourism Education, American University of } \\
\text { Madaba, Ajloun national University, Faculty of educational Sciences and Arts / } \\
\text { UNRWA. }\end{array}$ \\
\hline
\end{tabular}

The source: www.mohe.gov.jo

Through the exploration of previous literature by the two researchers, they found rarity in the studies that dealt with this study's topic in Jordanian universities sector despite its abundance in other sectors. Therefore the researchers will present the most suitable studies as follows:

- (Mubadeen, 2015) in his study of the impact of applying Balanced Scorecard on maximizing profitability in Jordanian Communication Companies, aimed at presenting scientific and theoretical concepts of Balanced Scorecard and identifying the extent to which Balanced Scorecard can be applied in Jordanian communication companies. He also aimed at identifying the obstacles to its application in Jordanian communication companies. To achieve the study's objectives, the researcher designed a questionnaire that was distributed to the study sample consisting of (135) individual, directors of 
departments and employees in these companies. The study results showed that Jordanian communication companies have the opportunity to apply Balanced Scorecard and this contributes in maximizing profitability and increasing its competitiveness.

- (Al-Azab, 2015), in his study: The application of Balanced Scorecard in Jordanian brokerage firms sought identifying the extent to which the non-financial indicators of Balanced Scorecard can be applied, in order to evaluate brokerage firms' performance comprehensively. In addition to identifying the impact of applying these indicators on companies' performance and the obstacles of application. The researcher concluded that Jordanian brokerage firms adapt standards related to internal processes perspective, standards related to learning and company's growth and related to customer's perspective. The researcher indicated that the most significant factor restricting the application of the non-financial perspective in brokerage companies is the lack of clarity in the vision and strategy of the company thus difficulty in identifying standards emerging from them. The researcher emphasizes that change resistance and difficulty of attaching weights to the importance of each non-financial perspective that hinders the application of non-financial perspective.

- The aim of the study by (Hussein, 2015) titled: The impact of the application of Balanced Scorecard on financial performance in Jordan's Private Hospitals, is to identify the impact of the application of non-financial perspective of Balanced Scorecard in Jordanian private hospitals on their financial performance, as well as to identifying the obstacles to the application of Balanced Scorecard perspectives in the private Jordanian hospitals. The study population consisted of all private Jordanian hospitals registered in Ministry of Health in 2014, total of (61) Hospital. Questionnaires were distributed to the general managers, directors of departments and accountants working in hospitals. The number of distributed questionnaires was (167) questionnaires, (144) of them valid for analysis were recovered. The study concluded a number of results, including: the keenness of private hospitals departments to highly apply non-financial perspectives of Balanced Scorecard, and the absence of basic or fundamental constraints which limit the application of the Balanced Scorecard perspectives in private Jordanian hospitals.

- The empirical study (Jarirah, 2014) titled: The extent of performance evaluation using the Balanced Scorecard perspective (BSC) in the public shareholding companies for food industries in Jordan: aimed to measure the extent of performance evaluating using four key performance of Balanced Scorecard perspective in public shareholding companies food industries in Jordan, in light of the large of investments in this sector and the use of modern industrial technologies, in addition to considering safety and quality. To achieve the objectives of the study, the researcher designed a questionnaire consisting of (24) items and was distributed to the study sample comprising of 160 employees. The researcher concluded that public shareholding companies for food industry in Jordan uses performance financial and non-financial measures to evaluate its performance, and these measures are related to the financial perspective, customer perspective, and internal processes perspective and learn and grow perspective. And the researcher confirmed the lack of full development of Balanced Scorecard usage.

- The case study of (Ahmad, 2014) in Greater Amman Municipality titled: Developing of Balanced Scorecard to evaluate strategic performance in non-profit organizations, aimed to identify the possibility of developing Balanced Scorecard as a mean to evaluate strategic performance in Greater Amman Municipality as one of the non-profit organization. To achieve the study objective, the researcher selected a study sample from managers and department directors by Stratified random sampling. The study followed a descriptive and 
analytical approach, and a questionnaire was designed and distributed to (123) respondent. The study concluded the competence of Balanced Scorecard as a tool to evaluate the strategic performance in the Greater Amman Municipality. The study showed that the elements of the application of Balanced Scorecard are available in case there is a genuine desire to be applied, and that there is acceptance by the respondents to apply it with various perspectives.

- The study of (Mwijuma et. al., 2013) titled: Effectiveness of Strategy Implementation Using the Balanced Scorecard in Local Government Authorities, aimed to address two issues: first, studying how local government authorities implement their strategies, and second, how to adopt the Balanced Scorecard as a tool to measure the effectiveness of strategy implementation in government organizations. In order to understand the use of the strategy in the local government authorities, this study has adopted the Balanced Scorecard as a way to evaluate the organization's performance and its moving towards achieving its objectives within the four key perspectives: the financial perspective, the customer perspective, internal processes perspective and learning and growth perspective. This research was conducted on 185 managers from the five government authorities chosen in Kenya Coast region. A questionnaire consisting of closed questions that asks the respondents to choose from a certain set of answers was used. Study results concluded the success of local government authorities in achieving their objectives in varying degrees.

- The study of (Al-Zwyalif, 2012) titled: The possibility of Implementing Balanced Scorecard in Jordanian Private Universities, aimed to identify the awareness degree of presidents of private Jordanian universities regarding the importance of applying Balanced Scorecard in addition to identifying the universities' ability to apply it through studying the provision of basic elements needed for application. To achieve the study's objective, the researches designed a questionnaire for this purpose and distributed to a sample of (151) individuals, Faculty deans, Heads of academic departments, financial directors and directors of different departments in private Jordanian universities. (130) of the questionnaires were considered valid for analysis. One of the most prominent results is that presidents of private Jordanian universities are aware of the importance of applying Balanced Scorecard in performance evaluation process. The provision of financial resources and qualified human resources are considered basic requirements for the application of Balanced Scorecard with its diverse perspectives. The researcher made recommendations about the importance of applying Balanced Scorecard in these universities and the promoting the awareness of universities presidents about the importance of actual initiating of applying Balanced Scorecard.

- The study of (Tohidi et. al., 2010) titled: Using Balanced Scorecard in Educational Organizations aimed to explain the importance of using Balanced Scorecard in governmental and educational institutions in Iran in order to evaluate performance through comparing planned performance with actual performance and that is for the assessment of the results of offering online educational services. The study concluded a number of results: The application of the Balanced Scorecard has led to maximizing returns by providing educational services through increasing the number of the beneficiaries and receivers of the service which reflected on the growth of returns as a result of performance improvement through the constant development according to performance evaluations through customers (students) point of view. The facilitating of providing of educational service and the constant change in the simplified user interface 
cause constant interaction between the user and the organization which is reflected on the student's satisfaction and consequently increasing the profits of providing services.

- The study (Kaplan \& Norton, 1992) titled: The Balanced Scorecard Measures that drive performance is considered the first study in Balanced Scorecard domain which is applied on twelve American companies that operates in different sectors. The two researchers explained a modern administrative approach to measure and evaluate companies' performance through four perspectives:

Financial perspective: it includes answering the question: how the company appears to be in front of its owners

Customer perspective: it includes answering the question: how the company appears to be in front of its customers.

Internal processes perspective: it includes answering the question: how the company conducts its diverse business and activities.

Learning and growth perspective: it includes answering: how do the employees view the company?

The study conducted that performance measurement model provides the administration with suitable information that helps in making diverse economical decisions because traditional systems of measuring performance based on Financial indicators and these standards alone is not enough to measure the overall performance of the company. One of the study's conclusion is that Balanced Scorecard model is a comprehensive system for measuring performance consisting of financial and non-financial standards. It is similar to the dashboard in the plane that enables the pilot to control all parts of the plane.

What distinguishes the current study from the previous ones is its addressing the application of Balanced Scorecard in Jordanian Universities specially that it was conducted as a comparative study of public and private Jordanian universities. A similar study was not conducted on this society with its environmental characteristic that differ (in some aspects) from the characteristics of environments in which previous studies were conducted as far as the researchers know. Also the high competitiveness of this sector on the local and regional level.

\section{STUDY HYPOTHESES}

For achieving study objectives and answering its questions, as well as according to what the previous studies concluded, the study hypotheses were formulated as follows:

H01: There is no implementation of balanced score card at Jordanian universities.

H02: There is no variation in implementing balanced score card between Jordanian public and private universities.

H03: There are no constraints (limitations) which limit the implementation of balanced score card at Jordanian universities.

H04: There is no variation in constraints (limitations) which limit the implementation of balanced score card between Jordanian public and private universities.

\section{Study Population}

The study population consisted of (28) Jordanian public and private universities; (10) public universities and (18) private universities, according to the statistics of Jordanian Ministry of Higher Education and Scientific Research at the beginning of 2017 listed in table (1). A comprehensive survey of study population were carried out; where the questionnaires were distributed to financial directors, internal auditing directors, quality control and assurance directors, heads of accounting departments and employees in financial sections of these universities. The researcher distributed and returned the questionnaires by hand. A number of distributed questionnaires was (336); (12) questionnaires for each university. A number of 
returned questionnaires was (264); (110) questionnaires from public universities and (154) questionnaires from private universities. It was shown the completeness of data in questionnaire as well as its appropriateness for statistical analysis. Accordingly, a number of adopted questionnaires for statistical analysis was (264) in (78.6\%) of distributed questionnaires.

The following table (Table 2) shows the distribution of questionnaires according to a sector of public and private universities:

Table (2)

A number of distributed and returned questionnaires

according to sectors of Jordanian universities

\begin{tabular}{|c|c|c|c|c|c|}
\hline $\begin{array}{c}\text { Sector } \\
\text { of } \\
\text { Jordani } \\
\text { an } \\
\text { Univers } \\
\text { ity }\end{array}$ & $\begin{array}{c}\text { Number } \\
\text { of } \\
\text { Universiti } \\
\text { es }\end{array}$ & $\begin{array}{l}\text { Number of } \\
\text { Distribute } \\
\text { d } \\
\text { Questionna } \\
\text { ires }\end{array}$ & $\begin{array}{c}\text { Number of } \\
\text { Returned and } \\
\text { Valid } \\
\text { Questionnaire } \\
\text { s for Analysis }\end{array}$ & $\begin{array}{c}\text { Percentage of } \\
\text { Returned and } \\
\text { Valid } \\
\text { Questionnaires } \\
\text { for Analysis }\end{array}$ & $\begin{array}{l}\text { Percentage of } \\
\text { Returned } \\
\text { Questionnaires } \\
\text { for Each Sector } \\
\text { from Total } \\
\text { Returned } \\
\text { Questionnaires }\end{array}$ \\
\hline Public & 10 & 120 & 110 & $\% 91.7$ & $\% 41.7$ \\
\hline Private & 18 & 216 & 154 & $\% 71.3$ & $\% 58.3$ \\
\hline Total & 28 & 336 & 264 & $\% 78.6$ & $\% 100$ \\
\hline
\end{tabular}

The previous table (Table 2) shows that the distribution of respondents of questionnaire questions was (41.7\%) of public universities and (58.3\%) of private universities. This variation is due to a large number of private universities compared with a number of public universities. The sector of universities was chosen as a study population because of scarcity of writings, researchers and studies about this sector, not to mention the vital role which this sector plays at the national and regional level.

\section{Methods of Data Collection}

It is referred to many researches and studies published in scientific journals and Periodicals regarding the topic of current research. In addition, the two researchers designed a questionnaire related to this study based on theoretical framework and previous studies, which was distributed to study population and returned by hand.

The questionnaire sections and questions related to measure study variables can be summarized in the following table (Table 3): 
Table (3) Questionnaire sections and questions related to measure study variables

\begin{tabular}{|l|l|l|}
\hline \multirow{4}{*}{$\begin{array}{l}\text { Questionnaire } \\
\text { Sections }\end{array}$} & Variable & $\begin{array}{l}\text { Questions } \\
\text { which } \\
\text { measure } \\
\text { variable }\end{array}$ \\
\hline \multirow{5}{*}{ First Section } & Age & 1 \\
\hline & Qualification & 2 \\
\cline { 2 - 3 } & Major & 3 \\
\hline & Position & 4 \\
\hline & Anumber of experience year in field of current work & 5 \\
\hline & The extent of participation in making decisions & 6 \\
\hline \multirow{5}{*}{ Second Section } & $\begin{array}{l}\text { The extent of implementing the dimension of } \\
\text { students (customers) as a one of balanced score card } \\
\text { dimensions }\end{array}$ & $(7-20)$ \\
\cline { 2 - 3 } & $\begin{array}{l}\text { The extent of implementing the dimension of } \\
\text { internal operations as a one of balanced score card } \\
\text { dimensions }\end{array}$ & $(21-34)$ \\
\cline { 2 - 3 } & $\begin{array}{l}\text { The extent of implementing the dimension of } \\
\text { learning and growth as a one of balanced score card } \\
\text { dimensions }\end{array}$ & $(35-48)$ \\
\hline & $\begin{array}{l}\text { The extent of implementing the financial dimensions } \\
\text { as a one of balanced score card dimensions }\end{array}$ & $(49-60)$ \\
\hline \multirow{5}{*}{ Third Section } & $\begin{array}{l}\text { Constraints which limit the implementation of } \\
\text { balanced score card dimensions }\end{array}$ & $(61-72)$ \\
\hline
\end{tabular}

It is worth mentioning that the second and third parts of questionnaire were formulated in the way that helps to ease the measurement; where 5-Point Likert Scale ranged between (Strongly Disagree, Disagree, Neutral, Strongly Agree, Agree) and classified to the following degrees $(1,2,3,4,5)$ respectively was adopted.

For testing the reliability of questionnaire results and the correlation among its questions, it was presented to a group of colleagues of university professors in departments of accounting and total quality management, as well as some specialists in field of internal auditing and quality control at Jordanian universities in order to judge and give their opinions regarding its formulation and the correlation among its paragraphs. In addition, reliability analysis was used to measure Cronbach's alpha. It was shown that its value is almost (88.1\%), where it exceeds the acceptable percentage (60\%) (Sekaran \& Bougie, 2015), which means the potentiality of adopting questionnaire results and assuring its reliability in achieving the study objectives.

\section{Methods of Data Analysis}

For the purposes of achieving study objectives and testing its hypotheses, the following statistical methods were used:

- Descriptive Statistics: some percentages, frequencies, means and standard deviations were calculated.

- T-test was used for one sample in order to test study hypotheses.

\section{Characteristics of Questionnaire Respondents}

Analysis of first part responses of questionnaire (Table 4) that the questionnaire respondents have an appropriate qualification; where all of them have a bachelor's degree at least. It is also observed that there are variety and promotion in position (financial director, director of quality control and assurance, director of internal auditing unit, accountant, internal auditor, financial auditor or employee of quality assurance) and this indicates their keeping up with developments of balanced scorecard as well as the importance of its implementation in improving performance and enhancing the competiveness of universities. Furthermore, it is observed that there is variety in scientific majors of respondents including accounting, 
business administration, banking and finance, economy, engineering and information technology by virtue of their different positions and job titles, and the largest percentage was accounting major with $(78.7 \%)$ of respondents.

It is also observed an increase in the level of their participation in making decisions, where a percentage of those who permanently or mostly contribute in making decisions were (83\%). What enhances the trust in concluded results is that the respondents have a high experience; where the concluded results showed that $(76.5 \%)$ of respondents have experience not less than five years in working in field of universities, which is considered a high percentage.

Accordingly, it is shown the potentiality of availability of knowledge in the balanced scorecard required for respondents as well as the importance of its implementation in improving the performance of Jordanian public and private universities and their abilities to understand and answer the questions of questionnaire.

Through comparing the demographic characteristics of respondents who work at public universities with those who work at private universities, it is observed the following:

- Similarity in ranging age within category (30- less than 40 years) at Jordanian public and private universities, However, noted that a percentage of those who are ( 40 years old or more) at public universities is larger than a percentage at private universities, perhaps the reason for that is job stability in governmental sector compared with private sector.

- An increase in percentage of those who have master's degree at private universities compared with a percentage of those who have a master's degree at public universities to the detriment of those who have a bachelor's degree, where their percentage exceeded at public universities compared with their percentage at private universities.

- A large convergence in the positions of respondents at the public and private universities, perhaps this is due to the specific job titles which two researchers chose to distribute questionnaires based on.

- An increase in a number of experience years in the current work for respondents at public universities compared with private universities, perhaps the reason of that is the job stability in governmental sector compared with private sector, as well as an increase in job turnover rate at private universities. 
Table (4)

Demographic Characteristics of Questionnaire Respondents

\begin{tabular}{|c|c|c|c|c|c|c|c|c|}
\hline \multirow[t]{2}{*}{ No. } & \multirow[t]{2}{*}{ Variable } & \multirow{2}{*}{$\begin{array}{c}\text { Answer } \\
\text { Alternatives }\end{array}$} & \multicolumn{2}{|c|}{$\begin{array}{c}\text { Sector of Public } \\
\text { Universities }\end{array}$} & \multicolumn{2}{|c|}{$\begin{array}{c}\text { Sector of Private } \\
\text { Universities }\end{array}$} & \multicolumn{2}{|c|}{$\begin{array}{c}\text { Total University } \\
\text { Sector }\end{array}$} \\
\hline & & & $\begin{array}{l}\text { Frequenc } \\
\text { ies }\end{array}$ & $\%$ & $\begin{array}{l}\text { Frequenc } \\
\text { ies }\end{array}$ & $\%$ & $\begin{array}{l}\text { Frequen } \\
\text { cies }\end{array}$ & $\%$ \\
\hline \multirow{5}{*}{1} & \multirow{5}{*}{ Age } & Less than 30 years & 17 & $\begin{array}{c}15.4 \\
\%\end{array}$ & 37 & $24 \%$ & 54 & $\begin{array}{c}20.4 \\
\%\end{array}$ \\
\hline & & $30-39$ years & 39 & $\begin{array}{c}35.4 \\
\%\end{array}$ & 69 & $\begin{array}{c}44.9 \\
\%\end{array}$ & 108 & $\begin{array}{c}40.9 \\
\%\end{array}$ \\
\hline & & $40-49$ years & 35 & $\begin{array}{c}\% 31 . \\
8\end{array}$ & 33 & $\begin{array}{c}21.4 \\
\%\end{array}$ & 68 & $\begin{array}{c}25.8 \\
\%\end{array}$ \\
\hline & & 50 years and more & 19 & $\begin{array}{c}17.4 \\
\%\end{array}$ & 15 & $9.7 \%$ & 34 & $\begin{array}{c}12.9 \\
\%\end{array}$ \\
\hline & & Total & 110 & $\begin{array}{c}100 \\
\%\end{array}$ & 154 & $\begin{array}{c}100 \\
\%\end{array}$ & 264 & $\begin{array}{c}100 \\
\%\end{array}$ \\
\hline \multirow{4}{*}{2} & \multirow[t]{4}{*}{ Qualification } & Bachelor's Degree & 90 & $\begin{array}{c}81.8 \\
\%\end{array}$ & 119 & $\begin{array}{c}77.3 \\
\%\end{array}$ & 209 & $\begin{array}{c}79.2 \\
\%\end{array}$ \\
\hline & & Master's Degree & 13 & $\begin{array}{c}11.8 \\
\%\end{array}$ & 25 & $\begin{array}{c}16.2 \\
\%\end{array}$ & 38 & $\begin{array}{c}14.4 \\
\%\end{array}$ \\
\hline & & PhD Degree & 7 & $6.4 \%$ & 10 & $6.5 \%$ & 17 & $6.4 \%$ \\
\hline & & Total & 110 & $\begin{array}{c}100 \\
\%\end{array}$ & 154 & $\begin{array}{c}100 \\
\%\end{array}$ & 264 & $\begin{array}{c}100 \\
\%\end{array}$ \\
\hline \multirow{6}{*}{3} & \multirow{6}{*}{ Major } & Accounting & 84 & $\begin{array}{c}76.3 \\
\%\end{array}$ & 124 & $\begin{array}{c}80.6 \\
\%\end{array}$ & 208 & $\begin{array}{c}78.7 \\
\%\end{array}$ \\
\hline & & $\begin{array}{c}\text { Business } \\
\text { Administration }\end{array}$ & 7 & $6.4 \%$ & 9 & $5.8 \%$ & 16 & $6.1 \%$ \\
\hline & & Economy & 7 & $6.4 \%$ & 4 & $2.6 \%$ & 11 & $4.2 \%$ \\
\hline & & Banking \& Finance & 9 & $8.2 \%$ & 12 & $7.8 \%$ & 21 & $8 \%$ \\
\hline & & $\begin{array}{l}\text { Others (Engineering } \\
\text { and Information } \\
\text { Technology (IT)) }\end{array}$ & 3 & $2.7 \%$ & 5 & $3.2 \%$ & 8 & $3 \%$ \\
\hline & & Total & 110 & $\begin{array}{c}100 \\
\% \\
\end{array}$ & 154 & $\begin{array}{c}100 \\
\% \\
\end{array}$ & 264 & $\begin{array}{c}100 \\
\%\end{array}$ \\
\hline \multirow{7}{*}{4} & \multirow{7}{*}{ Position } & Financial Director & 8 & $7.3 \%$ & 9 & $5.8 \%$ & 17 & $6.4 \%$ \\
\hline & & $\begin{array}{l}\text { Director of Internal } \\
\text { Auditing Unit }\end{array}$ & 5 & $4.5 \%$ & 11 & $7.1 \%$ & 16 & $6.1 \%$ \\
\hline & & $\begin{array}{l}\text { Director of Quality } \\
\text { Control \& Assurance }\end{array}$ & 4 & $3.6 \%$ & 6 & $3.9 \%$ & 10 & $3.8 \%$ \\
\hline & & Accountant & 72 & $\begin{array}{c}65.6 \\
\%\end{array}$ & 95 & $\begin{array}{c}61.8 \\
\%\end{array}$ & 167 & $\begin{array}{c}63.3 \\
\%\end{array}$ \\
\hline & & Internal Auditor & 17 & $\begin{array}{c}15.4 \\
\%\end{array}$ & 24 & $\begin{array}{c}15.6 \\
\%\end{array}$ & 41 & $\begin{array}{c}15.5 \\
\%\end{array}$ \\
\hline & & $\begin{array}{c}\text { Others (Financial } \\
\text { Auditor, Employee } \\
\text { of Quality } \\
\text { Assurance) }\end{array}$ & 4 & $3.6 \%$ & 9 & $5.8 \%$ & 13 & $4.9 \%$ \\
\hline & & Total & 110 & $\begin{array}{c}100 \\
\%\end{array}$ & 154 & $\begin{array}{c}100 \\
\%\end{array}$ & 264 & $\begin{array}{c}100 \\
\%\end{array}$ \\
\hline \multirow{6}{*}{5} & \multirow{5}{*}{$\begin{array}{l}\text { A number of } \\
\text { experience } \\
\text { years in the } \\
\text { current work }\end{array}$} & Less than 5 years & 19 & $\begin{array}{c}17.4 \\
\%\end{array}$ & 43 & $\begin{array}{c}27.9 \\
\%\end{array}$ & 62 & $\begin{array}{c}23.5 \\
\%\end{array}$ \\
\hline & & $5-9$ years & 27 & $\begin{array}{c}24.5 \\
\%\end{array}$ & 52 & $\begin{array}{c}33.8 \\
\%\end{array}$ & 79 & $\begin{array}{c}29.9 \\
\%\end{array}$ \\
\hline & & 10-14 years & 41 & $\begin{array}{c}37.2 \\
\%\end{array}$ & 35 & $\begin{array}{c}22.7 \\
\%\end{array}$ & 76 & $\begin{array}{c}28.8 \\
\%\end{array}$ \\
\hline & & 15 years and more & 23 & $\begin{array}{c}20.9 \\
\%\end{array}$ & 24 & $\begin{array}{c}15.6 \\
\%\end{array}$ & 47 & $\begin{array}{c}17.8 \\
\%\end{array}$ \\
\hline & & Total & 110 & $\begin{array}{c}100 \\
\%\end{array}$ & 154 & $\begin{array}{c}100 \\
\%\end{array}$ & 264 & $\begin{array}{c}100 \\
\%\end{array}$ \\
\hline & & Always & 31 & $\begin{array}{c}28.2 \\
\%\end{array}$ & 49 & $\begin{array}{c}31.8 \\
\%\end{array}$ & 80 & $\begin{array}{c}30.3 \\
\%\end{array}$ \\
\hline
\end{tabular}


Siam, W. Z., \& Al-Masri, R. N. (2017). The Extent of Applying the Balanced Scorecard at the Jordanian Universities: Comparative study between the Government and Private Universities. Archives of Business Research, 5(3), 166-194.

\begin{tabular}{|c|c|c|c|c|c|c|c|c|}
\hline \multirow{3}{*}{6} & $\begin{array}{c}\text { The extent of } \\
\text { participation in } \\
\text { making } \\
\text { decisions }\end{array}$ & Often & 57 & $\begin{array}{c}51.8 \\
\%\end{array}$ & 82 & $\begin{array}{c}53.2 \\
\%\end{array}$ & $\begin{array}{c}139 \\
\%\end{array}$ & $\begin{array}{c}52.7 \\
\%\end{array}$ \\
\cline { 3 - 9 } & & Sometimes & 13 & $\begin{array}{c}11.8 \\
\%\end{array}$ & 22 & $\begin{array}{c}14.3 \\
\%\end{array}$ & 35 & $\begin{array}{c}13.2 \\
\%\end{array}$ \\
\cline { 3 - 9 } & & Rarely & 9 & $\% 8.2$ & 1 & $0.7 \%$ & 10 & $\% 3.8$ \\
\cline { 3 - 9 } & & Never & - & - & - & - & - & - \\
\hline
\end{tabular}

\section{STUDY HYPOTHESES TEST}

\section{H01: "There is no implementation of balanced scorecard at Jordanian universities".}

For recognizing the extent of implementing balanced scorecard at Jordanian universities, the second section of questionnaire was set out, which consisted of four parts in order to measure the extent of implementing the four perspectives of balanced scorecard at Jordanian public and private universities jointly and separately.

Table (5) shows the results of statistical analysis of questions related to the extent of implementing balanced scorecard at Jordanian universities.

Table (5)

The extent of implementing balanced scorecard at Jordanian public and private universities

\begin{tabular}{|c|c|c|c|c|c|c|c|}
\hline \multirow[t]{2}{*}{ No. } & \multirow[t]{2}{*}{ Statements } & \multicolumn{2}{|c|}{$\begin{array}{c}\text { Sector of Public } \\
\text { Universities }\end{array}$} & \multicolumn{2}{|c|}{$\begin{array}{c}\text { Sector of Private } \\
\text { Universities }\end{array}$} & \multicolumn{2}{|c|}{$\begin{array}{c}\text { Total University } \\
\text { Sector }\end{array}$} \\
\hline & & Mean & $\begin{array}{l}\text { Standard } \\
\text { Deviation }\end{array}$ & Mean & $\begin{array}{l}\text { Standard } \\
\text { Deviation }\end{array}$ & Mean & $\begin{array}{l}\text { Standard } \\
\text { Deviation }\end{array}$ \\
\hline
\end{tabular}

First Part: The perspective of students (customers): this part aims to measure the extent of the actual implementation of the students' perspective as a one of balanced scorecard perspectives at Jordanian universities:

\begin{tabular}{|c|c|c|c|c|c|c|c|}
\hline .7 & $\begin{array}{l}\text { The administration of university } \\
\text { keens to recognize the level of } \\
\text { students and their parents' } \\
\text { satisfaction with the provided } \\
\text { services. }\end{array}$ & 2.72 & 0.71 & 3.64 & 0.77 & 3.10 & 0.87 \\
\hline .8 & $\begin{array}{l}\text { The administration of university } \\
\text { takes into consideration the } \\
\text { opinions of students regarding the } \\
\text { academic and administrative } \\
\text { performance of workers at } \\
\text { university. }\end{array}$ & 2.73 & 0.76 & 3.42 & 0.65 & 3.01 & 0.64 \\
\hline .9 & $\begin{array}{l}\text { The university provides students, } \\
\text { customers and visitors with ample } \\
\text { parking to achieve their } \\
\text { satisfaction. }\end{array}$ & 2.05 & 0.74 & 3.86 & 1.08 & 2.79 & 0.77 \\
\hline .10 & $\begin{array}{l}\text { Those who work in the } \\
\text { administration of university keens } \\
\text { to deal with students fairly and } \\
\text { indiscriminately. }\end{array}$ & 2.77 & 0.85 & 3.63 & 0.86 & 3.17 & 0.99 \\
\hline .11 & $\begin{array}{l}\text { The administration of university } \\
\text { cares for examining the extent of } \\
\text { increasing a number of students } \\
\text { from year to another. }\end{array}$ & 3.29 & 0.73 & 4.31 & 0.89 & 3.71 & 0.81 \\
\hline .12 & $\begin{array}{l}\text { The administration of university } \\
\text { achieves the students' satisfaction } \\
\text { which is not inconsistent with the } \\
\text { educational process. }\end{array}$ & 2.78 & 0.93 & 3.62 & 1.19 & 3.14 & 0.80 \\
\hline .13 & The administration of university & 2.91 & 0.82 & 3.70 & 1.04 & 3.24 & 0.97 \\
\hline
\end{tabular}




\begin{tabular}{|c|c|c|c|c|c|c|c|}
\hline & $\begin{array}{l}\text { keens to make students and } \\
\text { customers acquaint with } \\
\text { everything new at the university, } \\
\text { its facilitations and services. }\end{array}$ & & & & & & \\
\hline .14 & $\begin{array}{l}\text { The administration of university } \\
\text { pays adequate attention to the } \\
\text { requirements and needs of } \\
\text { students. }\end{array}$ & 2.69 & 0.81 & 3.60 & 0.95 & 3.06 & 0.72 \\
\hline .15 & $\begin{array}{l}\text { The administration of university } \\
\text { pays attention to feedback of } \\
\text { students and customers, and keens } \\
\text { to deal with them seriously. }\end{array}$ & 2.85 & 0.70 & 3.51 & 0.72 & 3.12 & 0.71 \\
\hline .16 & $\begin{array}{l}\text { The administration of university } \\
\text { provides an assessment tool to } \\
\text { take into consideration the } \\
\text { opinions of students and } \\
\text { customers regarding the provided } \\
\text { services. }\end{array}$ & 2.41 & 0.91 & 3.38 & 0.91 & 2.80 & 0.74 \\
\hline .17 & $\begin{array}{l}\text { The administration of university } \\
\text { sets out the students and } \\
\text { customers' satisfaction within } \\
\text { standards that it is based on to } \\
\text { measure its performance. }\end{array}$ & 2.43 & 0.60 & 3.36 & 0.62 & 2.83 & 0.83 \\
\hline .18 & $\begin{array}{l}\text { The administration of university } \\
\text { cares for decreasing a number of } \\
\text { students and customers' } \\
\text { complaints as an indicator of } \\
\text { service quality provided to them. }\end{array}$ & 2.56 & 0.60 & 3.54 & 0.70 & 2.97 & 0.75 \\
\hline .19 & $\begin{array}{l}\text { The administration of university } \\
\text { seeks to reduce a period of time } \\
\text { which customers spend in its } \\
\text { different facilities to get services } \\
\text { they need. }\end{array}$ & 2.61 & 0.55 & 3.61 & 0.73 & 3.02 & 0.74 \\
\hline .20 & $\begin{array}{l}\text { The administration of university } \\
\text { develops the relationships among } \\
\text { graduates and follows up their } \\
\text { conditions. }\end{array}$ & 1.75 & 0.85 & 3.22 & 1.01 & 2.36 & 0.69 \\
\hline \multicolumn{2}{|r|}{ Statements (7-20) jointly } & 2.59 & 0.76 & 3.77 & 0.87 & 3.28 & 0.68 \\
\hline \multicolumn{8}{|c|}{$\begin{array}{l}\text { Second Part: The perspective of internal operations: this part aims to measure the extent of the actual } \\
\text { implementation of the internal operations' perspective as a one of balanced scorecard perspectives at } \\
\text { Jordanian universities: }\end{array}$} \\
\hline .21 & $\begin{array}{l}\text { There is no delay in implementing } \\
\text { the procedures of registering } \\
\text { courses for students and paying } \\
\text { their fees. }\end{array}$ & 3.16 & 0.85 & 4.05 & 0.69 & 3.53 & 0.82 \\
\hline .22 & $\begin{array}{l}\text { The service quality is monitored in } \\
\text { each phase of providing it to } \\
\text { students and customers. }\end{array}$ & 2.59 & 0.88 & 3.27 & 0.81 & 2.87 & 0.91 \\
\hline .23 & $\begin{array}{l}\text { It is coordinated previously with } \\
\text { the concerned parties to provide } \\
\text { university with required } \\
\text { equipments and requirements of } \\
\text { the educational process in due } \\
\text { time and an appropriate quality. }\end{array}$ & 2.58 & 0.64 & 3.52 & 0.81 & 2.97 & 0.85 \\
\hline .24 & $\begin{array}{l}\text { The administration of university } \\
\text { seeks to provide an academic } \\
\text { atmosphere which contributes to } \\
\text { succeed the educational process. }\end{array}$ & 2.92 & 0.94 & 3.74 & 0.84 & 3.26 & 0.60 \\
\hline .25 & A decentralized system is adopted & 1.90 & 0.67 & 3.97 & 0.76 & 2.34 & 0.81 \\
\hline
\end{tabular}




\begin{tabular}{|c|c|c|c|c|c|c|c|}
\hline & $\begin{array}{c}\text { in managing the affairs of } \\
\text { university. }\end{array}$ & & & & & & \\
\hline .26 & $\begin{array}{l}\text { The administration of university } \\
\text { seeks to eliminate defectiveness in } \\
\text { the registration of students } \\
\text { resulting from the lack of skillful } \\
\text { workers at the university. }\end{array}$ & 2.62 & 0.70 & 3.55 & 1.02 & 3.00 & 0.77 \\
\hline .27 & $\begin{array}{c}\text { A new university services are } \\
\text { provided at a proper time. }\end{array}$ & 2.55 & 0.79 & 3.51 & 0.71 & 2.95 & 0.85 \\
\hline .28 & $\begin{array}{l}\text { The administration of university } \\
\text { seeks to develop the } \\
\text { administrative work systems } \\
\text { which help in a quick } \\
\text { accomplishment of services for } \\
\text { students. }\end{array}$ & 2.87 & 0.84 & 3.48 & 0.96 & 3.12 & 0.78 \\
\hline .29 & $\begin{array}{l}\text { The university uses the control } \\
\text { system of performance and } \\
\text { submits reports continuously to } \\
\text { higher management to follow up } \\
\text { performance directly. }\end{array}$ & 2.47 & 0.93 & 3.65 & 0.75 & 2.96 & 0.99 \\
\hline .30 & $\begin{array}{l}\text { Those who work in the } \\
\text { administration of university keens } \\
\text { to apply new technologies and } \\
\text { information systems in providing } \\
\text { services. }\end{array}$ & 2.71 & 0.81 & 3.91 & 0.73 & 3.21 & 0.75 \\
\hline .31 & $\begin{array}{l}\text { The systems at all universities } \\
\text { provide all required information } \\
\text { to accomplish services for } \\
\text { students quickly. }\end{array}$ & 2.62 & 0.91 & 3.64 & 0.81 & 3.04 & 0.74 \\
\hline .32 & $\begin{array}{l}\text { The administration of university } \\
\text { provides students, customers and } \\
\text { visitors with induction leaflets } \\
\text { which show the services provided } \\
\text { by university and concerned } \\
\text { department. }\end{array}$ & 2.90 & 0.72 & 3.96 & 0.84 & 3.34 & 0.71 \\
\hline .33 & $\begin{array}{l}\text { The administration of university } \\
\text { seeks to provide the highest } \\
\text { quality in performing its services } \\
\text { with the lowest possible cost. }\end{array}$ & 2.78 & 0.61 & 3.79 & 1.01 & 3.20 & 0.87 \\
\hline .34 & $\begin{array}{l}\text { The administration of university } \\
\text { set out an annual plan which } \\
\text { ensures work progress of } \\
\text { university and its development. }\end{array}$ & 2.44 & 0.94 & 3.60 & 0.74 & 2.91 & 0.68 \\
\hline \multirow{2}{*}{\multicolumn{8}{|c|}{ 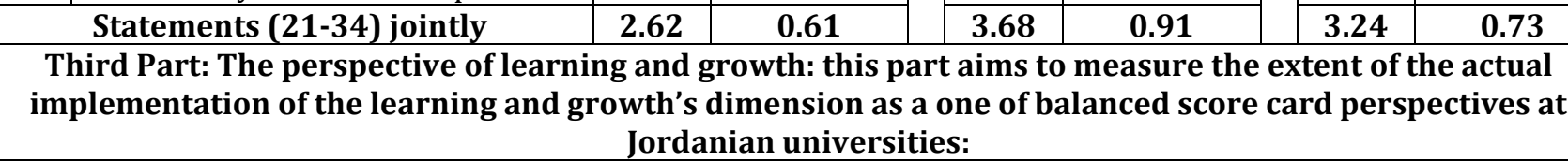 }} \\
\hline & & & & & & & \\
\hline .35 & $\begin{array}{l}\text { The university specifies an annual } \\
\text { amount for the research and } \\
\text { development processes in order to } \\
\text { improve provided services. }\end{array}$ & 3.02 & 0.86 & 3.87 & 0.87 & 3.37 & 0.87 \\
\hline .36 & $\begin{array}{l}\text { The administration of university } \\
\text { provides required techniques and } \\
\text { technological means to improve } \\
\text { provided educational services. }\end{array}$ & 2.85 & 0.61 & 3.57 & 0.71 & 3.15 & 0.81 \\
\hline .37 & $\begin{array}{l}\text { The continuous improvement and } \\
\text { development processes target } \\
\text { decreasing wasted time rate and } \\
\text { achieving desired objectives. }\end{array}$ & 2.59 & 0.82 & 3.43 & 0.73 & 2.94 & 0.71 \\
\hline .38 & The administration of university & 2.53 & 0.83 & 3.10 & 0.64 & 2.76 & 0.68 \\
\hline
\end{tabular}




\begin{tabular}{|c|c|c|c|c|c|c|c|}
\hline & $\begin{array}{l}\text { keens to develop the abilities of } \\
\text { administrators' and academicians } \\
\text { at the university. }\end{array}$ & & & & & & \\
\hline .39 & $\begin{array}{l}\text { The workers recognize university } \\
\text { mission and strategy clearly. }\end{array}$ & 2.39 & 0.87 & 3.21 & 0.63 & 2.73 & 0.69 \\
\hline .40 & $\begin{array}{l}\text { The administration of university } \\
\text { develops its organizational } \\
\text { procedures and systems. }\end{array}$ & 2.82 & 0.90 & 3.62 & 1.01 & 3.14 & 0.88 \\
\hline .41 & $\begin{array}{c}\text { The objectives of university are } \\
\text { characterized by realism and able } \\
\text { to achieve and measure } \\
\text { objectively. }\end{array}$ & 2.73 & 0.79 & 3.56 & 0.85 & 3.07 & 0.80 \\
\hline .42 & $\begin{array}{l}\text { The administration of university } \\
\text { uses new techniques according to } \\
\text { requirements of information } \\
\text { technology. }\end{array}$ & 2.95 & 0.74 & 3.68 & 0.76 & 3.25 & 0.95 \\
\hline .43 & $\begin{array}{l}\text { The administration of university } \\
\text { keens to develop innovation and } \\
\text { creativity skills in solving } \\
\text { problems for workers. }\end{array}$ & 2.25 & 0.88 & 3.03 & 0.86 & 2.55 & 0.86 \\
\hline .44 & $\begin{array}{l}\text { Those who work in the } \\
\text { administration of university keens } \\
\text { to have deanship or department } \\
\text { which is responsible for affairs of } \\
\text { quality and development. }\end{array}$ & 2.80 & 0.74 & 3.99 & 0.51 & 3.29 & 0.73 \\
\hline .45 & $\begin{array}{l}\text { The administration of university } \\
\text { keens to offer opportunities for } \\
\text { workers to develop their abilities } \\
\text { and skills and encourage the spirit } \\
\text { of initiative and creativity for } \\
\text { them. }\end{array}$ & 2.35 & 0.72 & 3.18 & 0.62 & 2.69 & 0.77 \\
\hline .46 & $\begin{array}{l}\text { The administration of university } \\
\text { keens to continue developing the } \\
\text { abilities of creativity and achieving } \\
\text { a higher status among universities. }\end{array}$ & 2.48 & 0.66 & 3.42 & 0.92 & 2.87 & 0.94 \\
\hline .47 & $\begin{array}{l}\text { The administration of university } \\
\text { keens to maintain, develop and } \\
\text { train creative human resources } \\
\text { which have experiences and } \\
\text { powers. }\end{array}$ & 2.13 & 0.80 & 3.01 & 0.93 & 2.50 & 0.66 \\
\hline .48 & $\begin{array}{l}\text { The administration of university } \\
\text { develops the current abilities and } \\
\text { skills of workers in order to reach } \\
\text { the target global level. }\end{array}$ & 2.10 & 0.75 & 3.12 & 0.94 & 2.52 & 0.78 \\
\hline & Statement (35-48) jointly & 2.49 & 0.78 & 3.51 & 0.83 & 3.09 & 0.81 \\
\hline \multicolumn{8}{|c|}{$\begin{array}{l}\text { Fourth Part: The financial dimension: this part aims to measure the extent of the actual implementation of } \\
\text { the financial dimension as a one of balanced scorecard perspectives at Jordanian universities: }\end{array}$} \\
\hline .49 & $\begin{array}{l}\text { The university uses the rate of } \\
\text { return for investment as an } \\
\text { indicator to assess its financial } \\
\text { performance. }\end{array}$ & 2.26 & 0.86 & 3.00 & 1.04 & 2.83 & 0.75 \\
\hline .50 & $\begin{array}{l}\text { The university uses the rate of } \\
\text { growth in revenues as an indicator } \\
\text { to assess it financial performance. }\end{array}$ & 2.17 & 1.39 & 3.33 & 0.97 & 2.74 & 0.74 \\
\hline .51 & $\begin{array}{l}\text { The university provides the local } \\
\text { and international programs which } \\
\text { increase the financial return. }\end{array}$ & 2.67 & 0.52 & 3.45 & 0.89 & 2.97 & 0.87 \\
\hline .52 & $\begin{array}{l}\text { The university uses the rate of net } \\
\text { cash flows of operational activities as } \\
\text { an indicator of its financial } \\
\text { performance. }\end{array}$ & 2.37 & 1.37 & 3.38 & 0.63 & 2.80 & 0.73 \\
\hline .53 & Those who work in the & 3.02 & 0.67 & 3.52 & 1.10 & 3.40 & 0.71 \\
\hline
\end{tabular}




\begin{tabular}{|c|c|c|c|c|c|c|c|}
\hline & $\begin{array}{l}\text { administration of university keen } \\
\text { to provide new programs in order } \\
\text { to increase its annual returns. }\end{array}$ & & & & & & \\
\hline .54 & $\begin{array}{l}\text { Available resources, properties } \\
\text { and returns of university are } \\
\text { invested in order to increase the } \\
\text { annual financial returns (profits). }\end{array}$ & 2.93 & 0.70 & 3.19 & 0.72 & 3.16 & 0.75 \\
\hline .55 & $\begin{array}{l}\text { The university uses the financial } \\
\text { measures as organizational } \\
\text { indicators of faculties and majors' } \\
\text { reality. }\end{array}$ & 2.46 & 0.41 & 3.94 & 0.62 & 2.90 & 1.02 \\
\hline .56 & $\begin{array}{l}\text { The university uses the liquidity } \\
\text { ratios as an indicator to assess the } \\
\text { financial performance. }\end{array}$ & 2.61 & 0.67 & 3.42 & 0.81 & 2.93 & 0.72 \\
\hline .57 & $\begin{array}{c}\text { The university uses the } \\
\text { profitability ratios as an indicator } \\
\text { to assess the financial } \\
\text { performance. }\end{array}$ & 2.48 & 0.79 & 3.39 & 0.71 & 2.88 & 0.85 \\
\hline .58 & $\begin{array}{l}\text { The university uses the activity } \\
\text { ratios as an indicator to assess the } \\
\text { financial performance. }\end{array}$ & 2.25 & 1.31 & 3.55 & 0.67 & 2.70 & 0.86 \\
\hline .59 & $\begin{array}{l}\text { The university keens to link } \\
\text { between the financial results and } \\
\text { the other indicators of } \\
\text { performance related to workers' } \\
\text { satisfaction. }\end{array}$ & 2.19 & 0.97 & 3.67 & 0.82 & 2.52 & 0.94 \\
\hline .60 & $\begin{array}{l}\text { Those who work in the } \\
\text { administration of university keens } \\
\text { to fit the prices of study hours } \\
\text { with number and quality of } \\
\text { services provided to the students. }\end{array}$ & 2.14 & 0.88 & 3.69 & 0.87 & 2.64 & 0.81 \\
\hline & Statements (49-60) jointly & 2.42 & 0.69 & 3.79 & 0.75 & 3.22 & 0.71 \\
\hline & $\begin{array}{c}\text { Statements (7-60) jointly } \\
\text { (Implementation of Balanced } \\
\text { Scorecard) }\end{array}$ & 2.53 & 0.71 & 3.68 & 0.81 & 3.21 & 0.76 \\
\hline
\end{tabular}

The last two columns of previous table (Table 5) show the means and standard deviations of paragraphs which measure the extent of implementing each dimension of balanced scorecard perspectives separately and the means and standard deviations which measure the extent of implementing balanced scorecard perspectives jointly at Jordanian universities.

According to the results mentioned in the previous table, it is observed that the highest implementation was (3.28) for the perspective of students (customers). In general, the mean of total paragraphs related to measure the extent of implementing balanced scorecard at Jordanian universities jointly was (3.21), which indicates a moderate degree of its implementation. In addition, the standard deviation which was (0.76) indicates that there is consistency and compatibility among individuals regarding the paragraphs of implementing balanced score card at Jordanian universities jointly.

For testing the first hypothesis, the t-test was used for one sample using a reference value which represents the mean of three Likert scale degrees. Table (6) shows the results of this hypothesis test: 
Table (6)

Results of first hypothesis test using t-test for one sample

\begin{tabular}{|c|c|c|c|c|c|c|c|}
\hline Variable & Mean & $\begin{array}{c}\text { Standar } \\
\mathrm{d} \\
\text { Deviatio } \\
\mathrm{n}\end{array}$ & $\begin{array}{c}\text { Calculat } \\
\text { ed “t” } \\
\text { Value }\end{array}$ & $\begin{array}{c}\text { Tabulate } \\
\mathrm{d} \text { " } \mathrm{t} \text { " } \\
\text { Value }\end{array}$ & $\begin{array}{c}\text { Degrees } \\
\text { of } \\
\text { Freedom }\end{array}$ & $\begin{array}{c}\text { Statistical } \\
\text { Significan } \\
\text { ce }\end{array}$ & $\begin{array}{c}\text { Result of } \\
\text { Hypothe } \\
\text { sis }\end{array}$ \\
\hline $\begin{array}{c}\text { The extent of } \\
\text { implementing } \\
\text { balanced score card at } \\
\text { Jordanian universities } \\
\text { jointly }\end{array}$ & $\mathbf{3 . 2 1}$ & $\mathbf{0 . 7 6}$ & $\mathbf{1 8 . 7 1}$ & $\mathbf{1 . 9 6}$ & $\mathbf{2 6 3}$ & $* \mathbf{0 . 0 0 0}$ & rejected \\
\hline
\end{tabular}

Statistical significant differences at the level of $(0.05)$

According to the results mentioned in the previous table, it is shown that the calculated " $\mathrm{t}$ " value which was (18.71) is higher than the tabulated " $t$ " value which was (1.96) and the level of significance $(\alpha)$ is less than (0.05), meaning that the null hypothesis is rejected and the alternative hypothesis is accepted; Jordanian universities jointly implement balanced scorecard.

The two researchers explain this results that Jordanian universities jointly (public and private) keen to implement balanced score card, although this implementation is still in a moderate level and does not reach the required level.

\section{Ho2: "There is no variation in implementing balanced scorecard between Jordanian public and private universities".}

The following table (Table 7) shows the summary of means and standard deviations which measure the extent of implementing each perspective of balanced scorecard perspectives separately and the means and standard deviations which measure the extent of implementing balanced scorecard perspectives jointly at Jordanian public and private universities individually.

Table (7)

Means and standard deviations of the extent of implementing balanced scorecard at Jordanian public and private universities

\begin{tabular}{|c|c|c|c|c|c|}
\hline \multirow{2}{*}{ No. } & Dimension & \multicolumn{2}{c|}{$\begin{array}{c}\text { Sector of Public } \\
\text { Universities }\end{array}$} & \multicolumn{2}{c|}{$\begin{array}{c}\text { Sector of Private } \\
\text { Universities }\end{array}$} \\
\cline { 2 - 5 } & Mean & $\begin{array}{c}\text { Standard } \\
\text { Deviation }\end{array}$ & Mean & $\begin{array}{c}\text { Standard } \\
\text { Deviation }\end{array}$ \\
\hline 1 & $\begin{array}{c}\text { Students (Customers) } \\
\text { Dimension }\end{array}$ & 2.59 & 0.76 & 3.77 & 0.87 \\
\hline 2 & Internal Operations Dimension & 2.62 & 0.61 & 3.68 & 0.91 \\
\hline 3 & Learning and Growth Dimension & 2.49 & 0.78 & 3.51 & 0.83 \\
\hline 4 & Financial Dimension & 2.42 & 0.69 & 3.79 & 0.75 \\
\hline \multicolumn{2}{|c|}{$\begin{array}{c}\text { The extent of implementing } \\
\text { balanced scorecard }\end{array}$} & $\mathbf{2 . 5 3}$ & $\mathbf{0 . 7 1}$ & $\mathbf{3 . 6 8}$ & $\mathbf{0 . 8 1}$ \\
\hline
\end{tabular}

According to the results mentioned in the previous table, it is observed that the means of each dimension of balanced scorecard dimensions at private universities are higher than means at public universities. In general, the mean of total paragraph related to measure the extent of implementing balanced scorecard at Jordanian private universities was (3.68) which is higher than the mean at Jordanian public universities which was (2.53), which indicates that it is implemented highly at private universities and moderately at public universities. This means that the null hypothesis is rejected and the alternative hypothesis is accepted; there is 
variation in implementing balanced scorecard between public and private universities and this variation is in favor of private universities.

The two researchers explain this result that the private universities, by virtue of its keenness on achieving the highest possible profitability, pay attention to the financial perspective as well as organization of internal operations and focus on customers (students) as well as learning and growth, which serve the interest of students at private universities more than the attention existed at public universities.

H03: "There are no constraints (determinants) which limit the implementation of balanced score card at Jordanian universities".

For recognizing the existence of constraints (determinants) which limit the implementation of balanced score card at Jordanian universities, the third section of questionnaire was set out.

Table (8) shows the results of statistical analysis of questions related to the existence of constraints (determinants) which limit the implementation of balanced score card at Jordanian universities.

Table (8)

The existence of constraints (determinants) which limit the implementation of balanced scorecard at Jordanian public and private universities

\begin{tabular}{|c|c|c|c|c|c|c|c|}
\hline \multirow[t]{2}{*}{ No. } & \multirow[t]{2}{*}{ Statements } & \multicolumn{2}{|c|}{$\begin{array}{l}\text { Sector of Public } \\
\text { Universities }\end{array}$} & \multicolumn{2}{|c|}{$\begin{array}{c}\text { Sector of Private } \\
\text { Universities }\end{array}$} & \multicolumn{2}{|c|}{$\begin{array}{c}\text { Total Jordanian } \\
\text { Universities }\end{array}$} \\
\hline & & Mean & $\begin{array}{l}\text { Standard } \\
\text { Deviation }\end{array}$ & Mean & $\begin{array}{l}\text { Standard } \\
\text { Deviation }\end{array}$ & Mean & $\begin{array}{l}\text { Standard } \\
\text { Deviation }\end{array}$ \\
\hline \multicolumn{8}{|c|}{ The constraints (determinants) which limit the implementation of balanced scorecard at your university: } \\
\hline .61 & $\begin{array}{l}\text { There is no competencies able to } \\
\text { collect and analyze data in order } \\
\text { to implement the perspectives of } \\
\text { balanced scorecard }\end{array}$ & 3.04 & 0.85 & 3.04 & 0.81 & 3.04 & 0.71 \\
\hline .62 & $\begin{array}{l}\text { Explaining university mission to } \\
\text { multiple strategic perspectives is } \\
\text { considered inappropriate for the } \\
\text { nature of university work. }\end{array}$ & 2.58 & 0.96 & 2.55 & 0.90 & 2.57 & 0.56 \\
\hline .63 & $\begin{array}{l}\text { The administration of university } \\
\text { considers that the cost of } \\
\text { implementing balanced scorecard } \\
\text { is high. }\end{array}$ & 3.01 & 0.61 & 2.82 & 0.84 & 2.91 & 0.91 \\
\hline .64 & $\begin{array}{c}\text { Implementing the perspectives of } \\
\text { balanced scorecard is difficult } \\
\text { because it includes many } \\
\text { measures which are } \\
\text { uncontrollable. }\end{array}$ & 2.82 & 0.76 & 2.78 & 0.75 & 2.85 & 0.63 \\
\hline .65 & $\begin{array}{l}\text { It is difficult to subject all } \\
\text { objectives of university to the } \\
\text { qualitative and quantitative } \\
\text { measurement through objective } \\
\text { indicators and measures. }\end{array}$ & 2.92 & 0.76 & 2.84 & 0.67 & 2.87 & 0.87 \\
\hline .66 & $\begin{array}{l}\text { The higher administration of } \\
\text { university set out the strategic } \\
\text { plans and implements them } \\
\text { without involving the different } \\
\text { departments of university in } \\
\text { setting out these plans. }\end{array}$ & 2.86 & 0.88 & 2.65 & 0.72 & 2.78 & 0.87 \\
\hline .67 & $\begin{array}{l}\text { The administrative systems at the } \\
\text { university do not advance to the required } \\
\text { level to implement the dimensions of } \\
\text { balanced scorecard. }\end{array}$ & 3.02 & 0.73 & 2.48 & 0.79 & 2.80 & 0.95 \\
\hline
\end{tabular}




\begin{tabular}{|c|c|c|c|c|c|c|c|}
\hline .68 & $\begin{array}{l}\text { The routine of provided services } \\
\text { at the university prevents the } \\
\text { potentiality of developing its } \\
\text { services. }\end{array}$ & 3.19 & 0.98 & 2.45 & 0.81 & 2.89 & 0.67 \\
\hline .69 & $\begin{array}{l}\text { The absence of continuous update } \\
\text { for the legal regulations at the } \\
\text { university to keep up with new } \\
\text { events. }\end{array}$ & 2.99 & 0.95 & 2.49 & 0.86 & 2.79 & 0.81 \\
\hline .70 & $\begin{array}{l}\text { The administration of university } \\
\text { does not have adequate } \\
\text { knowledge in the methods of } \\
\text { assessing strength and weakness } \\
\text { points through analyzing the } \\
\text { internal operations of university. }\end{array}$ & 2.80 & 1.01 & 2.42 & 0.74 & 2.66 & 0.67 \\
\hline .71 & $\begin{array}{l}\text { The continuous change in the } \\
\text { instructions which are set out by } \\
\text { the ministry of higher education } \\
\text { and universities accreditation } \\
\text { commission. }\end{array}$ & 3.17 & 0.76 & 2.89 & 0.82 & 3.01 & 0.73 \\
\hline .72 & $\begin{array}{l}\text { The strategic decisions of } \\
\text { administration of university do } \\
\text { not take into consideration the } \\
\text { requirements of students and } \\
\text { customers and their need. }\end{array}$ & 2.69 & 0.86 & 2.68 & 0.68 & 2.68 & 0.75 \\
\hline \multicolumn{2}{|r|}{$\begin{array}{c}\text { Statements (61-72) jointly } \\
\text { (constraints (determinants) of } \\
\text { implementing balanced scorecard) }\end{array}$} & 2.83 & 0.85 & 2.76 & 0.73 & 2.80 & 0.93 \\
\hline
\end{tabular}

The last two columns in the previous table (Table 8) show the means and standard deviations of paragraphs which measure the existence of constraints (determinants) which limit the implementation of balanced score card at Jordanian universities jointly (both public and private).

According to the results mentioned in the previous table, it is shown the following:

It is observed that the highest mean was (3.04) for paragraph No. (61) of questionnaire paragraphs, which indicates that the respondents emphasize that the most important constraint of implementing balanced scorecard at Jordanian universities generally (public and private) is non-existence of competencies able to collect and analyze data to implement balanced score card. In addition, the standard deviation which was (0.71) indicates that there are consistency and compatibility among individuals regarding these paragraphs.

The mean which was (2.57) for paragraph No.(62) of questionnaire paragraphs indicates that the respondents consider that the statement stating "Explanation of university mission to multiple strategic dimensions is inappropriate for the nature of university work" is considered less influential constraint which could face the implementation of balanced scorecard at Jordanian universities generally.

In general, the mean of total paragraphs related to measure the extent of existence of constraints (determinants) which limit the implementation of balanced scorecard at Jordanian universities generally (public and private) was (2.80), which indicates that these constraints are existent in a moderate level. In addition, the standard deviation which was (0.93) indicates that there are relative consistency and compatibility among individuals regarding these paragraphs generally. 
For testing the third hypothesis, the t-test was used for one sample using a reference value which represents the mean of three Likert scale degrees. Table (9) shows the results of this hypothesis test:

Table (9)

Results of third hypothesis test using t-test for one sample

\begin{tabular}{|c|c|c|c|c|c|c|c|}
\hline Variable & $\begin{array}{c}\text { Mea } \\
\mathbf{n}\end{array}$ & $\begin{array}{c}\text { Standar } \\
\text { d } \\
\text { Deviatio } \\
n\end{array}$ & $\begin{array}{c}\text { Calculat } \\
\text { ed “t” } \\
\text { Value }\end{array}$ & $\begin{array}{c}\text { Tabulat } \\
\text { ed “t” } \\
\text { Value }\end{array}$ & $\begin{array}{c}\text { Degre } \\
\text { es of } \\
\text { Freed } \\
\text { om } \\
\end{array}$ & $\begin{array}{c}\text { Statistica } \\
1 \\
\text { Significa } \\
\text { nce }\end{array}$ & $\begin{array}{c}\text { Result } \\
\text { of } \\
\text { Hypoth } \\
\text { esis }\end{array}$ \\
\hline $\begin{array}{c}\text { The existence of } \\
\text { constraints } \\
\text { (determinants) which } \\
\text { limit the } \\
\text { implementation of } \\
\text { balanced scorecard at } \\
\text { Jordanian universities } \\
\text { jointly (public and } \\
\text { private) }\end{array}$ & 2.80 & 0.93 & 18.37 & 1.96 & 263 & *0.000 & rejected \\
\hline
\end{tabular}

Statistical significant differences at the level of $(0.05)$

According to the results mentioned in the previous table, it is shown that the calculated " $t$ " value which was (18.37) is higher than the tabulated " $t$ " value which was (1.96) and the level of significance $(\alpha)$ is less than (0.05), meaning that the null hypothesis is rejected and the alternative hypothesis is accepted; there are constraints (determinants) which limit the implementation of balanced scorecard at Jordanian universities jointly (public and private).

The two researchers consider that this result is logical, where the results of first hypothesis test indicates the existence of moderate implementation of balanced scorecard, therefore, there are no essential constraints which prevent the implementation of balanced score card. However, there are moderate constraints (determinants) which limit the complete implementation of balanced scorecard at Jordanian universities jointly (public and private).

H04: "There is no variation in constraints (determinants) which limit the implementation of balanced scorecard between Jordanian public and private universities".

The following table (Table 10) shows the summary of means and standard deviations which measure constraints (determinants) of implementing balanced scorecard at Jordanian public and private universities individually.

Table (10)

Means and standard deviations of constraints (determinants) of implementing balanced scorecard at Jordanian public and private universities

\begin{tabular}{|c|c|c|c|c|}
\hline \multirow{2}{*}{ constraints (Determinants) } & \multicolumn{2}{|c|}{$\begin{array}{c}\text { Sector of Public } \\
\text { Universities }\end{array}$} & \multicolumn{2}{c|}{$\begin{array}{c}\text { Sector of Private } \\
\text { Universities }\end{array}$} \\
\cline { 2 - 5 } & Mean & $\begin{array}{c}\text { Standard } \\
\text { Deviation }\end{array}$ & Mean & $\begin{array}{c}\text { Standard } \\
\text { Deviation }\end{array}$ \\
\hline $\begin{array}{c}\text { The implementation of balanced } \\
\text { scorecard at Jordanian public and } \\
\text { private universities }\end{array}$ & $\mathbf{2 . 8 3}$ & $\mathbf{0 . 8 5}$ & $\mathbf{2 . 7 6}$ & $\mathbf{0 . 7 3}$ \\
\hline
\end{tabular}

According to the results mentioned in the previous table, it is observed that the mean of existence of constraints (determinants) at public universities is higher than the mean at 
private universities. What enhances this result is the means of each constraint (determinant) mentioned in table (8), where it is shown an increase in means of each constraint (determinant) jointly and separately at public universities compared with private universities.

In general, the mean of total paragraphs related to measure the existence of constraints (determinants) which limit the implementation of balanced scorecard at Jordanian public universities which was (2.83) is higher than the mean at Jordanian private universities which was (2.76). This indicates that the null hypothesis is rejected and the alternative hypothesis is accepted, meaning that there is variation in the existence of constraints (determinants) which limit the implementation of balanced scorecard between Jordanian public and private universities and this variation is in favor of the private universities.

The two researchers explain this result that the private universities, by virtue of its keenness on achieving the highest possible profitability, pay attention to provide appropriate means in order to attract the largest number of students and overcome all constraints and difficulties which would prevent students to enroll in these universities. Therefore, they reduce constraints (determinants) of implementing balanced scorecard as a tool of assessing performance more than what the public universities perform in this regard.

\section{STUDY RESULTS AND CONCLUSIONS}

In light of data analysis and hypotheses test, the following results and conclusions was concluded:

1. Jordanian universities generally (public and private) implements the perspectives of balanced scorecard (jointly and separately) moderately, where the mean of their implementation jointly was (3.21). The sequence of implementing these perspectives descending is as follows: students (Customers) perspective, internal operations perspective, financial perspective, learning and growth perspective, where their means were $(3.09,3.22,3.24,3.28)$ respectively.

2. It is observed that there is variation in degree of implementing balanced scorecard among Jordanian universities and this variation is in favor of Jordanian private universities.

3. There are constraints (determinants) which limit the implementation of balanced scorecard at Jordanian universities and these constraints are not essential due to their moderate degree (their mean was 2.80).

4. There is a simple variation in degree of constraints (determinants) which limit the implementation of balanced scorecard between Jordanian public and private universities and in favor of private universities, where the mean of existence of constraints for public and private universities was $(2.76,2.83)$ respectively.

5. When examining the existence of constraints (determinants) which limit the implementation of balanced scorecard at Jordanian public and private universities, the results show that there is consistency among respondents at public and private universities regarding the most influential constraint: the existence of shortcoming in the competencies which are able to collect and analyze data in order to implement balanced scorecard, in addition to the continuous change in the instructions which the ministry of higher education and scientific research as well as the higher education accreditation commission set out. 


\section{RECOMMENDATIONS AND SUGGESTIONS}

In light of the results which were concluded, the two researchers recommended the following:

1. Enhancing the implementation of balanced score card at Jordanian public and private universities through raising awareness for their administrations and owners regarding the importance of implementing this card and the advantage achieved by its implementation.

2. The private universities have to pay more attention to learning and growth perspective particularly, where the results of statistical analysis show that the level of implementing this perspective is the lowest among the four perspectives.

3. The private universities have to enhance its keenness on students' (customers) satisfaction without affecting on the quality of educational process and outcomes, for example, providing ample and appropriate parking for students, customers and visitors to achieve their satisfaction as well as developing the relationship with graduates and following up their conditions, even if it is needed to establish a specialized unit in deanship of student affairs for this purpose.

4. Concreting the efforts of Jordanian public and private universities in order to prevent the reasons of constraints (determinants) of implementing balanced scorecard optimally, along with keening on providing competencies able to collect and analyze data in order to implement balanced score card, in addition to coordinate with the ministry of higher education and scientific research, the higher education accreditation commission and other concerned parties to prevent the continuous change in the instructions which these parties set out.

5. Finding ways to enhance the collaboration between the administrations and workers of public and private universities at their different positions in order to activate the implementation of balanced scorecard as an effective way to help the universities remaining and achieving the competitive advantage with the increased competition and the globalization challenges.

\section{References}

Ahmad, Fadyah, 2014, Developing a Balanced Scorecard Model for Evaluating Strategic Performance in Non-Profit Organizations: A Case Study of Greater Amman Municipality, Ph.D. Dissertation, World Islamic Sciences and Education University, Jordan.

Al-Azab, Hani Abdel Hafez, 2015, The Implementation of Balanced Scorecard in Jordanian Brokerage Firms, ElBahith Review, Kasdi Merbah University, Algeria, No. 15, pp: 59-68.

Al-Gharib, Abujailah Ramadan, 2012, The Extent of Using Balanced Scorecard in Performance Evaluation at Libyan Commercial Banks, Middel East University, Jordan.

Al-Khatatneh, Waheed R. and Al-Sa`aydeh, Mansour I., 2009, The Level of Awareness of Jordanian Industrial Public Companies`Managers of the Sigificance of the Non-Financial Perspectives (Measures) of the Balanced Scorecard (BSC) in Evaluating the Performance of their Companies, Jordan Journal of Business Administration, University of Jordan, Jordan, Vol. 5, No. 1, pp: 1-18.

Al-Safani, Abdalsalam Abdallah, 2012, Using Benchmarking Technique to support the Balanced Scorecard on firm value maximization: A field study in Yemen environment, Master Thesis, Helwan University, Egypt.

Al-Zwyalif, Inaam M., 2012, The possibility of Implementing Balanced Scorecard in Jordanian Private Universities, International Business Research, Vol. 5, No. 11, pp: 113-120. 
Bernardo Guimaraes, Pedro Simoes, and Rui Cunha Marques, 2010, Does performance evaluation help public managers? A Balanced Score card approach in urban waste services, Journal of Environmental Management, Vol. 91, No. 12, pp: 2632-2638.

Bhimani, Alnoor; Horngren, Charles; Datar, Srikant; and Rajan, Madhav, 2015, Management and Cost Accounting, $6^{\text {th }}$ ed., Pearson, Boston.'

Campbell, D., 2002, Using the Balanced Scorecard as a control system for Monitoring and revising Corporate, Social Science Researchs, Vol. 4, No. 2. pp: 1-45.

Denis Simon Ombuna, Karim Omido, Hamadi Musa Garashi, Odhiambo Odera, Ochieng Okaka, 2013, "Impact of Balanced Scorecard Usage on the Performance of Commercial Banks", International Journal of Information Technology and Business Management, Vol.10, No.1. pp: 13-27.

Durgham, Maher Mousa and Abu Feddah, Marwan Mohammad, 2009, The Effect of Implementing Balanced Scorecard (BSC) in Enhancing StrategicFinancial Performance of National Palestinian Banks that are actively working in Gaza Strip: A field study, The Islamic University Journal of Humanities Research, Palestine, Vol. 17, No. 2, pp: 741-788.

Greiling, H., 2010, Balanced Scored Implementation in German Non -Profit Organization, Journal of Accounting Research, Vol. 44, pp: 151-178.

Hussein, Ala`a, 2015, The Effect of Applying the Balanced Scorecard on the Financial Performance in the Jordanian Private Hospitals, Master Thesis, The Hashemite University, Jordan.

Jarirah, Talal, 2014, The extent of performance evaluation by using the dimensions of Balanced Scorecard (BSC) in the foods industrial companies in Jordan: A field study, Journal of Dirasat: Series of Administrative Sciences, University of Jordan, Jordan, Vol. 41, No. 2, pp: 23-47.

Kaplan, Robert S.; Matsumura, Ella M.; Young, S. Mark; and Atkinson, Anthony A., 2011, Management Accounting Information for Decision - Making and Strategy Execution, $6^{\text {th }}$ ed., Pearson, Boston.

Kaplan, R., and Atkinson, A., 1998, Advanced Management Accounting, $3^{\text {rd }}$ ed., Prentice Hall, New Jersey.

Kaplan, R., and Norton, D., 1992, The Balanced Scorecard - Measures That Drive Performance, Harvard Business Review, Vol. 70, pp: 71-79.

Kaplan, R., and Norton, D., 2004, Translating Strategy into Action: The Balanced Scorecard, Harvard University Press, Boston.

Kumari, N., 2011, Balanced Scorecard for Superior Organizational Performance European, Journal of Business and Management, Vol 3, No.5, pp: 73-86.

Mubaideen, Saif Mahammad Theeb, 2015, The Impact of Balabced Scorecard Applying on Profit Maximization in Jordanian Telecommunications Companies, Ph.D. Dissertation, World Islamic Sciences and Education University, Jordan.

Mwijuma, Shufaa; Omido, Karim; Garashi, Hamadi; Odera, Odhiambo; and Akerele, Emmanuel, 2013, Effectiveness of Strategy Implementation Using the Balanced Scorecard in Local Government Authorities, International Journal of Management and Business Studies, Vol 3, No.1, pp: 146-151.

Perlman, Yael., 2013, Causal Relationships In The Balanced Scorecard: A Path Analysis Approach, Journal of Management and Strategy, Vol. 4, No. 1, pp: 70-79.

Sekaran, Uma and Bougie, Roger, 2015, Research Methods for Business: A Skill Building Approach, $5^{\text {th }}$ ed., John Wiley and Sons Inc, USA.

Sleihat, Nimer Abdel-Hamid and Almahamid, Soud Mohammad, 2013, The Impact of Knowledge Management Practices on Balanced Scorecard: An empirical Investigation in Small-Meduim-Size Manufacturing Companies, Jordan Journal of Business Administration, University of Jordan, Jordan, Vol. 9, No. 1, pp: 1-21.

Tohidi, H., Jafari A., Azimi A., 2010, Using balanced scorecard in educational organization, Procedia-Social and Behavioral Sciences, Vol. 2, No. 2, pp: 145-163.

Werner, Michael I., and Xu, Fuyuan, 2012, Executing Strategy with the Balanced Scorecard, International Journal of Financial Research, Vol. 3, No. 1, pp: 88-94.

Zaghloul, Gouda Abdel-Raouf, 2010, Using Balanced Scorecard for Constructing A Quadripartite Measuring Model for Managing Strategic and Operational Performance of Intellectual Assets, Research presented at $12^{\text {th }}$ Seminar: 
Siam, W. Z., \& Al-Masri, R. N. (2017). The Extent of Applying the Balanced Scorecard at the Jordanian Universities: Comparative study between the Government and Private Universities. Archives of Business Research, 5(3), 166-194.

The Ways to development the Accounting in Saudi Arabia (Accounting Prifessional in Saudi Arabia and the Challengesof Twenteith Century), pp: 13-29, King Saud University, Saudi Arabia.

http://www.mohe.gov.jo/ar/pages/Vision- Mission.aspx\#sthash.BNi1Y9Mz. dpuf, Available at: 25/1/2017. http://www.mohe.gov.jo/ar/pages/PrivateUniversities.aspx\#sthash.ZAglCAil.dpuf Available at: 25/1/2017. http://www.mohe.gov.jo/ar/pages/StateUniversities.aspx\#sthash.dligCxI6.dpuf, Available at: 25/1/2017. 